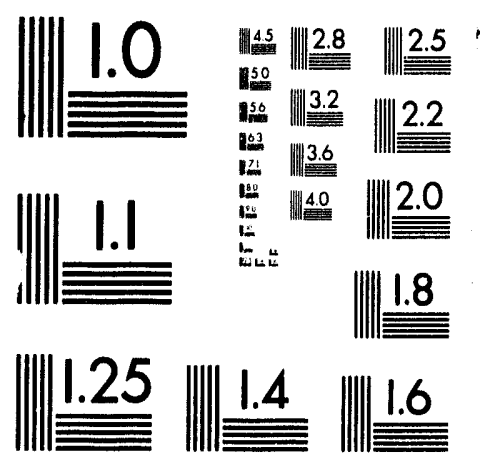



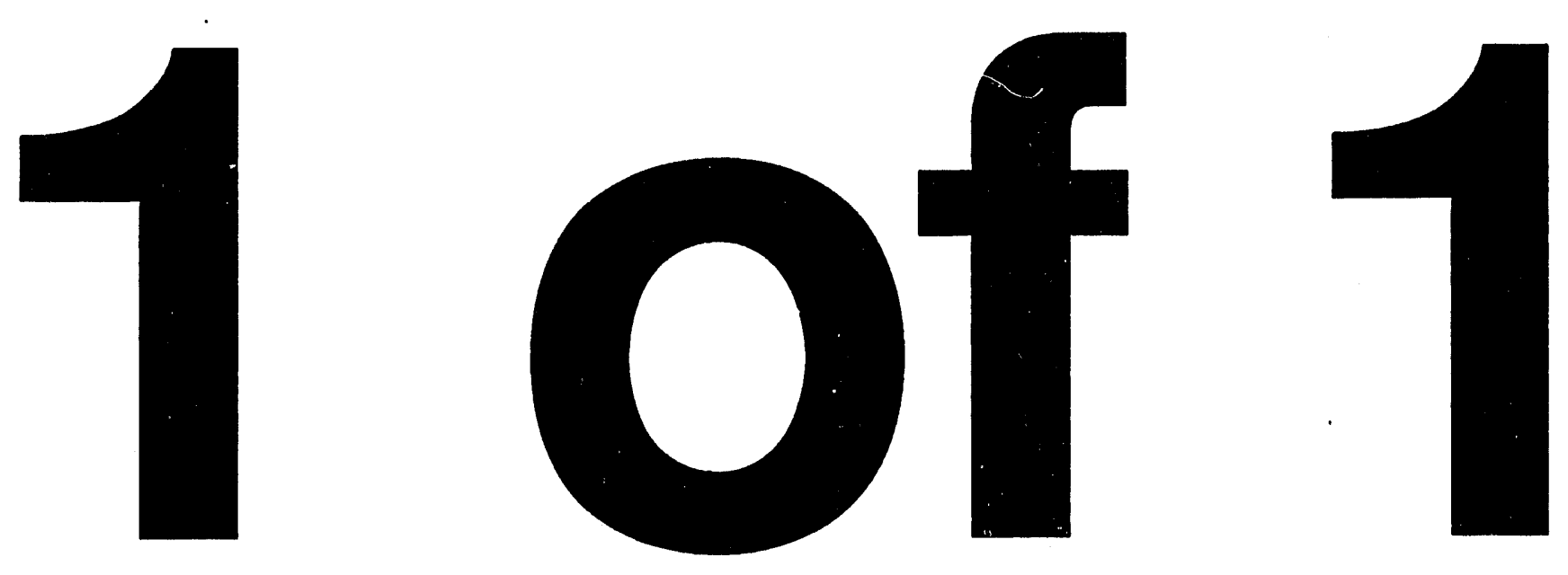


\title{
Integrated Low Emissions Cleanup System for Direct Coal Fueled Turbines
}

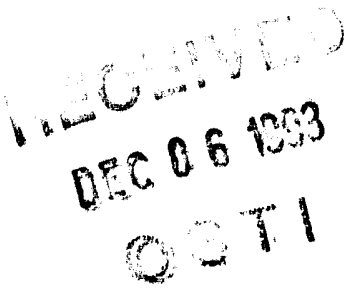

Topical Report

\author{
R.A. Newby \\ M.A. Alvin \\ D.M. Bachovchin \\ E.E. Smeltzer \\ T.E. Lippert
}

July 1993

Work Performed Under Contract No.: DE-AC21-87MC24257

For

U.S. Department of Energy

Office of Fossil Energy

Morgantown Energy Technology Center

Morgantown, West Virginia

By

Westinghouse Electric Corporation

Science \& Technology Center

Pittsburgh, Pennslyvania 


\section{DISCLAIMER}

This report was prepared as an account of work sponsored by an agency of the United States Government. Neither the United States Government nor any agency thereof, nor any of their employees, makes any warranty, express or implied, or assumes any legal liability or responsibility for the accuracy, completeness, or usefulness of any information, apparatus, product, or process disclosed, or represents that its use would not infringe privately owned rights. Reference herein to any specific commercial product, process, or service by trade name, trademark, manufacturer, or otherwise does not necessarily constitute or imply its endorsement, recommendation, or favoring by the United States Government or any agency thereof. The views and opinions of authors expressed herein do not necessarily state or reflect those of the United States Government or any agency thereof.

This report has been reproduced directly from the best available copy.

Available to DOE and DOE contractors from the Office of Scientific and Technical Information, P.O. Box 62, Oak Ridge, TN 37831; prices available at (615) 576-8401.

Available to the public from the National Technical Information Service, U.S. Department of Commerce, 5285 Port Royal Rd., Springfield, VA 22161; phone orders accepted at (703) 487-4650. 


\section{Integrated Low Emissions Cleanup System for Direct Coal Fueled Turbines}

Topical Report

Work Performed Under Contract No.: DE-AC21-87MC24257

For

R.A. Newby

M.A. Alvin

D.M. Bachovchin

E.E. Smeltzer

T.E. Lippert

\author{
U.S. Department of Energy \\ Office of Fossil Energy

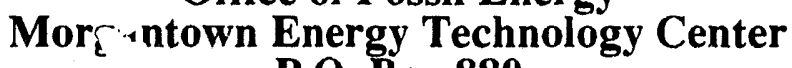 \\ P.O. Box 880 \\ Morgantown, West Virginia 26507-0880
}

By

Westinghouse Electric Corporation

Science \& Technology Center

1310 Beulah Road

Pittsburgh, Pennslyvania 15235

July 1993 


\section{DISCLAIMER}

This report was prepared as an account of work sponsored by the United States Government. Neither the United States nor the United States Department of Energy, nor any of their employees, makes any warranty, express or implied, or assumes any legal liability or responsibility for the accuracy, completeness, or usefulness of any information, apparatus, product, or process disclosed, or represents that its use would not infringe privately owned rights. Reference herein to any specific commercial product, process, or service by trade name, mark, manufacturer, or otherwise, does not necessarily constitute or imply its endorsement, recommendation, or favoring by the United States Government or any agency thereof. The views and opinions of authors expressed herein do not necessarily state or reflect those of the United States Government or any agency thereof.

\section{PATENT STATUS}

This technical report is being transmitted in advance of DOE patent clearance and no further dissemination or publication shall be made of the report without prior approval of the DOE Patent Counsel.

\section{TECHNICAL STATUS}

This technical report is being transmitted in advance of DOE review and no further dissemination or publication shall be made of the report without prior approval of the DOE Project/Program Manager. 


\begin{abstract}
The United States Department of Energy, Morgantown Energy Research Center (DOE/METC), is sponsoring the development of coal-fired turbine technology in the areas of Pressurized Fluidized Bed Combustion, Integrated Gasification Combined Cycles, and Direct Coal-Fired Turbines. A major technical challenge remaining for the development of coal-fired turbine systems is high-temperature gas cleaning to meet environmental standards for sulfur oxides and particulate emissions, as well as to provide acceptable turbine life.

The Westinghouse Electric Corporation, Science \& Techinology Center, is evaluating an Integrated Low Emissions Cleanup (ILEC) concept that has been configured to meet this technical challenge. This ceramic barrier filter, ILEC concept simultaneously controls sulfur, particulate, and alkali contaminants in high-pressure fuel gases or combustion gases, and is considering cleaning temperatures up to $2100^{\circ} \mathrm{F}$. This document describes Phase II of the program, the design, construction, and shakedown of a bench-scale facility to test and confirm the feasibility of this ILEC technology.
\end{abstract}




\section{INTRODUCTION}

Development of coal-fueled turbine power cycles, Pressurized Fluidized Bed Combustion (PFBC), Advanced Fluidized Bed Combustion (APFBC), Integrated Gasification Combined Cycle (IGCC), and Direct CoalFired Turbines (DCFT) is focused on providing high performance, compact and low cost power generation systems. These advanced power generation systems demand high performance from hot-gas cleaning equipment to meet environmental requirements and to satisfy turbine protection requirements. The hot gas cleaning concepts are currently undemonstrated.

To provide emissions control and turbine protection from gasand solid-phase contaminants in coal-fired turbine systems, new approaches for sulfur and alkali control may be required at the proposed temperature levels of some coal-fired systems, and new approaches for particulate control may be required in environments of potentially molten and/or sticky flyash particles. An integrated, multi-function cleaning stage may be an economic requirement when using minimallycleaned, high-sulfur, high-ash coals.

In this program, an advanced, high-temperature, Integrated Low Emissions Cleanup (ILEC) concept is addressed that combines particulate and gas phase contaminant removal in a single, compact filter device that is intended for operation in coal-fueled turbine systems. The program investigates the key process and design parameters of the concept. Finely sized sulfur and alkali sorbents are injected into the raw gas stream, react with the gas-phase sulfur and alkali species while modifying the sticky nature of the coal ash in the stream. Sorbent and 
ash particles are collected on ceramic barrier filters placed in the contactor vessel. Additives may also be injected to control the filter cake behavior.

The program has been divided into three phases. Phase $I$ of the program deals with critical laboratory testing and conceptual commercial design evaluation. Phase I has been completed. Phase II, the upgrading of a HTHP bench-scale facility to demonstrate the features of the ILEC, has taken place. Phase II is the focus of this report. Phase III involves the HTHP bench-scale testing and engineering assessment of the ILEC system. 


\section{WESTINGHOUSE ILEC CONCEPT}

The Westinghouse ILEC concept is an extrapolation and combination of gas cleaning phenomena previously studied and developed for similar technical purposes in other applications. These basic technologies are:

- ceramic barrier filter particulate control,

- sulfur sorbent injection into high-temperature gas streams,

- alkali sorbent injection into high-temperature gas streams.

Ceramic barrier filters have the potential to provide extremely high particle removal efficiencies at high gas temperatures. Testing at temperatures up to $1700^{\circ} \mathrm{F}$ in PFBC, APFBC, and IGCC environments has shown that they can exceed the particulate removal needed for both environmental standards and for turbine erosion and deposition protection. One concern for their use in some coal-fired turbine applications is that adhesive particles (slag particles or sticky fly ash particles) may be emitted from the gas producer that will form a filter cake that is difficult to remove from the filter elements by normal pulse cleaning. It is the premise of the ILEC concept proposed in this program that the adhesive particles will interact with added sorbent particles, or with specific additive particles to modify the filter cake adhesive nature so that it will be removable by standard pulse cleaning. This premise is applied in the ILEC concept pictured in Figure 2.1.

In the concept shown in Figure 2.1, the ILEC system is a ceramic barrier filter vessel having a design much like that of the ceramic barrier filters vessels being developed specifically for particle 
control in current PFBC, APFBC, and IGCC programs. An array of filter elements, candle-type, bag-type, cross-flow type, or others, is supported from a tube sheet, and is housed in a refractory-lined pressure vessel. Filter cake is periodically released from the filter elements by back-pulsing with clean gas. The released filter cake drops into a conical bin at the base of the vessel for removal. The ILEC concept is operated with the injection of sulfur sorbents, alkali sorbents, and possibly selected deposit-modifying additives (e.g., kaolin) that produce a filter cake on the filter elements that is easily removed by pulsed cleaning.

The potential success of the baseline ILEC concept is suggested by deposit formation observed in other programs that inject sulfur sorbents into conventional coal-fired furnaces, and programs that have injected deposit additives into coal-fired turbine gases. ${ }^{1,2,3}$ The injected sulfur sorbents are -325 mesh calcium-based sorbents, that effectively capture $\mathrm{SO}_{2}$ at the turbine inlet temperatures in the relatively short contact times available. The injected alkali sorbent is -325 mesh emathlite, hectorite, or others, that remove alkali species (sodium and potassium components) from the gas to meet projected turbine alkali limits. The effectiveness of emathlite, and other alkali sorbents such as hectorite, has been demonstrated at a small-scale at temperatures up to about $1600^{\circ} \mathrm{F}$ in both reducing and oxidizing gases. ${ }^{4}$ 


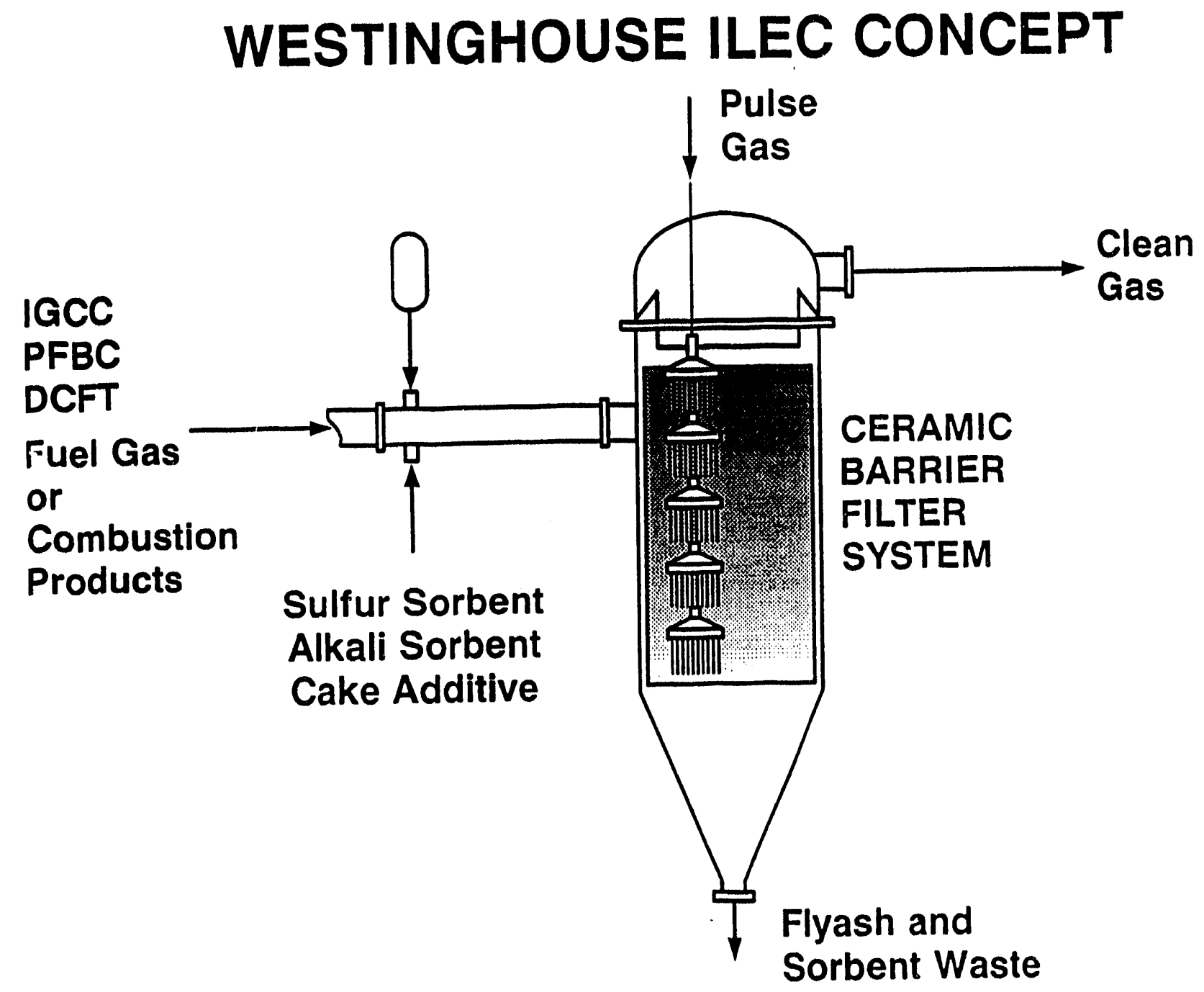

Figure 2.1 - ILEC Concept 


\section{PROGRAM STRUCTURE AND OBJECTIVES}

The program is being conducted in three phases to demonstrate, at the bench scale, the ILEC concept. Phase I of the program has been completed. Phase I of the program dealt with laboratory sulfur and alkali sorbent screening tests, cold flow testing, and commercial system evaluation of various ILEC concepts to support the bench-scale facility design and testing in Phases II and III. In Phase II, upgrading of an existing, high temperature, high pressure (HTHP) facility located at the Westinghouse Science \& Technology Center has taken place. The facility was upgraded for partial coal/natural gas combustion to attain a range of combustion gas conditions. This facility will be used in Phase III to test the components and advanced design features of the ILEC system, and to verify the engineering design principles of the concept.

Phase II, the subject of thias report, consists of four major tasks.

Task II-1 - Test Plan Development

Objective: Devise a test plan for the bench-scale facility test program based on the Westinghouse ILEC concept.

Scope: Include integrated particle, sulfur, and alkali removal performance, deposit additive, characteristics of the filter cake, pressure drop, pulse cleaning, and materials. Focus the testing on temperatures beyond prior ceramic barrier filter experience -- $1850^{\circ} \mathrm{F}$ to $2100^{\circ} \mathrm{F}$. Estimate test conditions to evaluate the performance of simulated coal-fired turbine operation in DCFT and PFBC with the Westinghouse ILEC concept. 


\section{Task II-2 - Bench-Scale Facility Modification Design}

Objective: Develop the design of the facility for the ILEC concept bench-scale testing that meets the test plan requirements.

Scope: Utilize the existing HTHP filter test facility modified for

- temperatures up to $2100^{\circ} \mathrm{F}$

- oxidizing environments simulating DCFT and PFBC

- combined partial coal/methane firing

- sulfur removal with calcium-based sorbents

- alkali sorbent injection

- deposit additives

- candle filters elements

Select :

- appropriate candle material for this duty

- appropriate instrumentation for $\mathrm{SO}_{\mathbf{x}}$, and alkali measurement

- sorbent and additive feeding equipment and feed nozzles

Prepare:

- material and energy balances

- process flow diagrams

- equipment sizes, designs, and specifications

- equipment drawings

Task II-3 - Bench-Scale Facility Fabrication and Assembly

Objective: Prepare the facility for testing the ILEC system by modifying the existing HTHP test facility as required.

Scope: Fabricate the facility modifications and required new test components. Purchase equipment, candle filters, and instruments. Assemble the facility. Procure and characterize sulfur sorbents, alkali sorbents, deposit additives, coals, and coal ashes. 
Task II-4 - Bench-Scale Shakedown Testing

Objective: Conduct shakedown testing of the modified bench-scale facility and instruments to demonstrate the operating capabilities and compatibility with the design requirements.

Scope: Operate the modified facility at maximum and minimum flow test conditions. Operate coal, ash, sorbent and additive feed equipment. Confirm accuracy of instrumentation. 


\section{ILEC TEST PLAN}

The ILEC major test parameters and selected levels of variation are:

- coal type (2 types, Coal A and Coal B)

- temperature (2 levels, nominally 1850 and $2100^{\circ} \mathrm{F}$ )

- sulfur sorbent (2 types, at $2 \mathrm{Ca} / \mathrm{S}$ molar feed ratios)

- alkali sorbent (1 type at 2 feed levels)

- deposit additives ( 2 at 2 feed levels)

The selected testing sequence for the program is:

- Preliminary tests

- Tests at $1850^{\circ} \mathrm{F}$ with Coal A

- Tests at $2100^{\circ} \mathrm{F}$ with Coal A

- Tests with Coal B at a selected temperature

These test sequence steps are defined as follows.

\section{Preliminary Tests}

Test 1. Natural Gas Combustion

Purpose: Confirm natural gas burner performance, general operability and temperature capability.

- Natural gas firing at $1850^{\circ} \mathrm{F}, 10 \mathrm{~atm}$.

- Natural gas firing at $2100^{\circ} \mathrm{F}, 10 \mathrm{~atm}$. 
Test 2. $\mathrm{SO}_{2}$ Removal

Purpose: Confirm operability of $\mathrm{SO}_{2}$ system, sorbent feed system, and $\mathrm{SO}_{2}$ measuring system. Precondition filters with sulfur sorbent. Produce baseline $\mathrm{SO}_{2}$ removal data and baseline filter data.

- Inject $\mathrm{SO}_{2}$ gas at about 500 ppmv.

- Operate at 1850 and $2100^{\circ} \mathrm{F}$.

- Feed 2 sulfur sorbents (lime hydrate and dolomite).

- Feed with $2 \mathrm{Ca} / \mathrm{S}$ molar feed ratios.

- Inspect filters and combustor.

\section{Tests at $1850^{\circ} \mathrm{F}$ with Coal A}

Test 3. Coal Combustion

Purpose: Confirm coal feed system and coal combustor performance. Measure $\mathrm{SO}_{2}$ and alkali emission with no sorbents. Generate filter data with no sorbents or additives. Confirm general operability.

- Continue run for maximum of 1 shift.

- Inspect filters and combustor/ clean if necessary.

Test 4. Coal Sulfur Removal

Purpose: Measure $\mathrm{SO}_{2}$ removal performance with coal firing. Measure influence of sulfur sorbent on alkali release. Determine impact of sulfur sorbent on filter performance.

- Inject $\mathrm{SO}_{2}$ gas if needed.

- Measure $\mathrm{SO}_{2}$ and alkali at filter outlet.

- Feed 2 sulfur sorbents (lime hydrate and dolomite).

- Feed with $2 \mathrm{Ca} / \mathrm{S}$ ratios.

- Compare performance with Test 3 . 
- Continue run for maximum of completion of parametrics (4 hours per $\mathrm{Ca} / \mathrm{S}$ ratio).

- Inspect filters and combustor.

- Contingency: If filter performance problem during Test 4, feed deposit additive ( 2 additives at 2 feed rates).

Test 5. Coal Alkali Removal

Purpose: Measure alkali sorbent effectiveness. Measure impact of alkali sorbent on filter performance.

- Operate with 1 sulfur sorbent at $1 \mathrm{Ca} / \mathrm{S}$ ratio.

- Feed 1 alkali sorbent at 2 feed rates.

- Measure $\mathrm{SO}_{2}$ and alkali at filter outlet.

- Compare performance with Test 3.

- Continue run for maximum of completion of parametrics (4 hours per feed rate).

- Inspect filters and combustor.

- Contingency: If filter performance problem during Test 5, feed deposit additive ( 2 additives at 2 feed rates).

Test 6. Integrated Long-Term Test

Purpose: Perform 100 hour continuous test with best conditions from the prior tests. Demonstrate significant sulfur removal, alkali removal, and filter operability.

- Operate with 1 sulfur sorbent at $1 \mathrm{Ca} / \mathrm{S}$ ratio.

- Feed 1 alkali sorbent at 1 feed rate.

- Measure $\mathrm{SO}_{2}$ and alkali at filter outlet.

- Compare performance with prior tests.

- Continue run until filter performance problem or for maximum of 100 hours.

- Inspect filters and combustor. 
Tests at $2100^{\circ} \mathrm{F}$ with Coal $\mathrm{A}$

Tests 7 - 10 (analogous to Tests $3-6$ )

Tests with Coal B at a Selected Temperature

Tests $11-14$ (analogous to Tests $3-6$ ) 


\section{CONCEPTUAL DESIGN OF THE BENCH-SCALE FACILITY}

A natural gas-fired, bench-scale, high-pressure, hightemperature (HTHP) test facility previously operated at Westinghouse STC for the development of ceramic barrier filters was selected to be modified to study ILEC performance under simulated coal-fired turbine conditions.

The specific task steps followed for completing the modification design are listed in Table 5.1. They are listed in their natural order although many were conducted in parallel.

\subsection{DESIGN CONCEPT}

The features of the existing test facility that required modification were associated with the desire to perform partial coalfiring in combination with natural gas, to do simultaneous sulfur and alkali sorbent, and filter cake additive injection into the combustion gas stream, and to operate the filter vessel at significantly higher temperatures than the current facility. Designs evaluations were required for

- a coal-natural gas combustor

- modifiec filter vessel gas inlet, insulation, and liners

- a new filter tubesheet

- a coal feed system

- sorbent and additive feed system

- new water-cooled exhaust line

- instrumentation for $\mathrm{SO}_{2}$ and alkali vapor measurement 


\section{Table 5.1 - Bench-Scale Test System Design Steps}

1. Select design concepts for ILEC components

2. Identify system constraints

- Safety and environmental

- Space, height, weight, and flow limits

3. Conduct preliminary process (M\&E balances, I\&C diagrams) and hardware (major vessel sizes and features; layout) designs that include heat loss analysis; set auxiliary component requirements.

4. Develop preliminary safety, environmental and operating procedures

5. Select temperature, flow and pressure control systems

6. Specify process measurements and inspection needs

- coal feed rate and ultimate composition

- fly ash feed rate and compositions

- alkali feed rate $(\mathrm{NaCl})$

- $\mathrm{SO}_{2}$ gas feed rate

- combustor primary and secondary air feed rates

- methane feed rate

- sulfur sorbent feed rate and composition

- alkali sorbent feed rate and composition

- additive feed rate and composition

- filter exhaust gas composition ( $\mathrm{SO}_{2}$ and alkali content)

- filter inlet gas composition ( $\mathrm{SO}_{2}$ and alkali content)

- filter solid waste composition

- combustor, dilution zone, and filter vessel temperature profile

- combustor, dilution zone, and filter vessel pressure profile

- filter vessel and filter element inspection

7. Select instrumentation, data acquisition, sampling, and analytical methods

8. Conduct design and cost review for management, safety, environmental and facilities approvals

9. Conduct detailed hardware design/ obtain vendor and shop information and quotes

10. Prepare design report. 
Coal-Natural Gas Combustor

There are many types of coal/natural gas combustor design concepts that could be applied. The concepts considered ranged from simple modifications of the existing methane-fired combustor, where a small amount of coal is injected either radially or axially into the methane flame, to advanced, water-cooled, slagging combustor designs, such as a design of a partial coal- and methane-fired combustor having a capacity close to the needs of the Westinghouse STC program had been developed by AVCO for use in another DOE program. Evaluation of these design concepts resulted in the selection of a new refractory-lined, modified natural gas combustor with axial injection of pulverized coal because of its simplicity and flexibility.

The internals for the coal-natural gas combustor were initially considered to be ceramic tubing, and materials samples of alumina, zirconia, and mullite were received, as well as preliminary cost quotes for the ceramic internals. The combustor materials were changed to a high-alloy steel capable of $2500^{\circ} \mathrm{F}$ operation to provide better thermal shock performance, a major concern for the combustor ceramic internals, as well as being considerably cheaper. Ultimately, a refractory-lined combustor was selected to eliminate the complex cooling design of the high-alloy internals.

Filter Vessel Hot Gas Inlet, Insulation, and Liner Designs

The hot gas inlet to the filter vessel was also conceptually considered. Sticky particles contained in the combustion products may deposit on any shroud or baffle that the gas impinges on. Various options were considered, but it was decided that no inlet baffle should be used to avoid operational difficulties. A radial inlet having no baffle or shroud, with the gas entering at an elevation below the tips of the candle filter elements will be used. The quadrant of the vessel interior opposite the gas inlet will be empty so that the diverging flow 
from the gas inlet will not impinge directly on the filter elements. Cold flow modeling of this configuration was performed to confirm its operability.

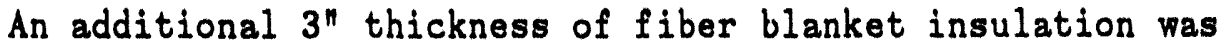
determined to be sufficient to minimize the vessel heat losses and maintain the metal shell temperature at a safe level. A high-alloy liner was specified to cover the fiber blanket insulation and also provided support for the insulation.

\section{Filter Vessel Tubesheet}

Options for the filter vessel tubesheet design that were considered are: 1) ceramic tubesheet, 2) water- or air-cooled tubesheet, and 3) conductively-cooled tubesheet. A quote for the purchase of a commercially-available ceramic tubesheet, and information on some of the ceramic tubesheet properties was received from Didier (Germany). The uncertainty in the ceramic tubesheet performance, its high cost and long delivery time, make it undesirable for this test program. The water- or air-cooled tubesheet appears to be complex to design and probably expensive to fabricate. It also may promote temperature gradients that could result in ceramic filter element failures. The third option of using conduction heat losses through the metal tubesheet expansion coupling and the vessel flange, with insulation added on both faces of the tubesheet, appears to be feasible based on preliminary calculations and was selected for the program.

A simple heat transfer model of the tubesheet with a top and bottom layer of insulation, connected to the metallic expansion coupling and to the pressure vessel flange was developed to assess the feasibility of using conductive cooling, and to select the design conditions required to maintain the tubesheet at temperatures typical of normal test practice experience (about $1600^{\circ} \mathrm{F}$ ).

It is concluded that this is a viable option for operating the test unit at high temperatures. It appears to be considerably simpler than water- or air-cooling of the tubesheet and does not have the 
uncertainties of ceramic tubesheets. The desired design conditions for this option are:

- 3 inches of insulation on each face of the tube sheet and over the first expansion region

- an expansion coupling thickness of $1 / 4^{n}$

- an extended tubesheet ring that protrudes past the flange to increase heat losses.

It may a].so be helpful to include thermal radiation shielding for the tubesheet and to provide convective cooling air circulation over the ressel flange and extended tubesheet ring.

\subsection{PRELIMINARY PROCESS DESIGN}

A preliminary process design has been performed for the purpose of defining the basis for the modified facility design. Material and energy balances for both a generic, commercial direct coal-fired turbine system, and for a range of bench-scale test systems were generated. The generic, commercial configuration and the bench-scale simulation configuration are conceptually pictured in Figure 5.1. The objective of the bench-scale simulation is to produce a gas having pressure, temperature, gas composition $\left(\mathrm{SO}_{2}\right.$, alkali content, and particulate content), and particulate composition similar to commercial combustors. The commercial configuration will have low heat losses compared to the simulation, will be entirely coal fired, and will probably have considerable slag removal before the filter. The material balance assumptions and resulting flow rates and compositions for the commercial configuration operating at a bench-scale flow rate of 80 acfm are shown in Table 5.2. Two temperatures, 1850 and $2100^{\circ} \mathrm{F}$ are considered. The coal is a bituminous coal containing 1 wt\% sulfur and 10 wt\% ash. 


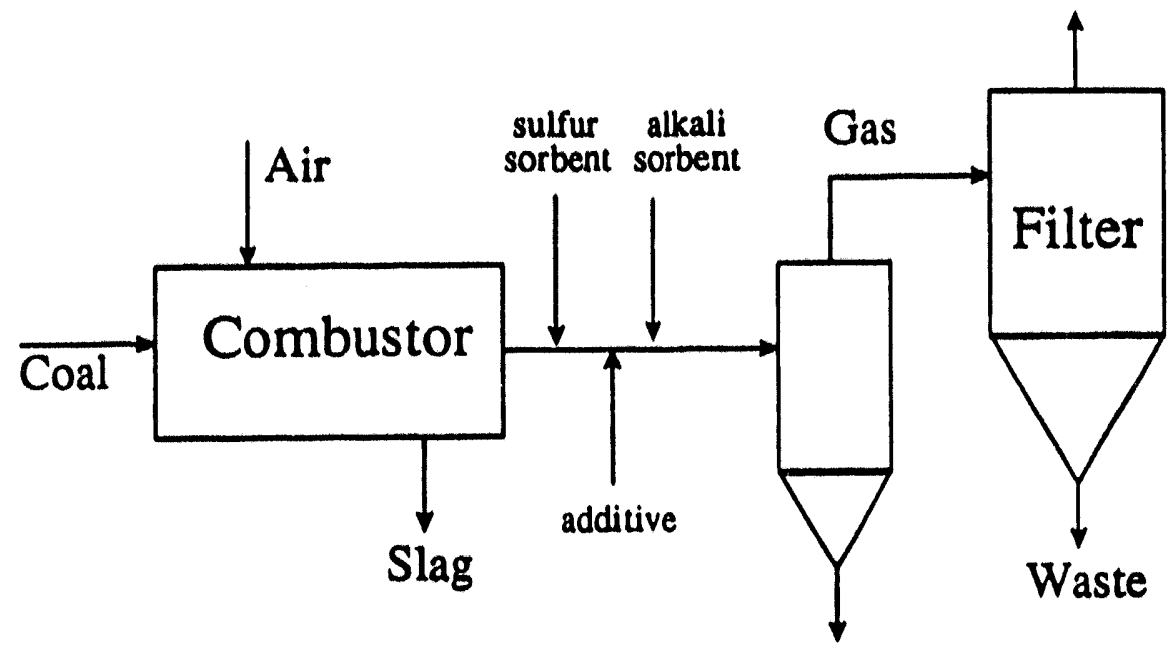

\section{COMMERCIAL CONFIGURATION}

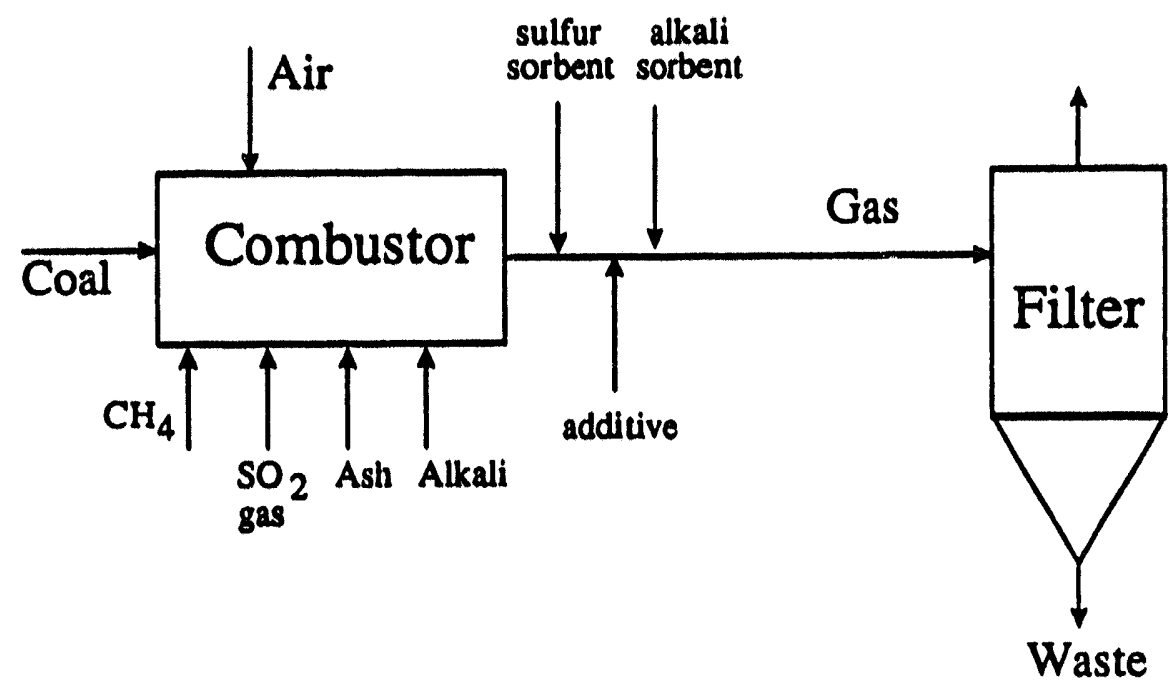

\section{BENCH-SCALE SIMULATION}

Figure 5.1 - Commercial DCFT Process Configuration 
Table 5.2 - Commercial Configuration

- Coal -- Pgh \#8; 1 wt\% S, 10 wt\% ash

- Coal contains $0.4 \%$ alkali $(\mathrm{Na}+\mathrm{K}) ; 3 \%$ alkali release

- No heat losses

- Dolomite $\mathrm{Ca} / \mathrm{S}$ of 2 ; $90 \%$ sulfur removal

- $600^{\circ} \mathrm{F}$ air inlet temperature

- $80 \%$ slag removal (coal ash only)

- No cyclone

- Operating pressure 10 atm

- Gas flow 90 acfm

\begin{tabular}{|c|c|c|c|c|c|c|c|c|c|}
\hline \multirow[b]{2}{*}{$\begin{array}{l}\text { Temp } \\
\text { (F) }\end{array}$} & \multicolumn{5}{|c|}{ Flow Rates } & \multicolumn{4}{|c|}{ Uncontrolled Gas } \\
\hline & Air & Coal & $\begin{array}{l}\text { Sulfur } \\
\text { sorbent }\end{array}$ & $\begin{array}{l}\text { Alkali } \\
\text { sorbent }\end{array}$ & $\begin{array}{r}\text { Filter } \\
\text { waste }\end{array}$ & $\begin{array}{l}\text { Gas } \\
\mathrm{SO}_{2}\end{array}$ & $\begin{array}{l}\text { Gas } \\
\text { alkali }\end{array}$ & $\begin{array}{l}\text { Part. } \\
\text { load }\end{array}$ & $\begin{array}{c}\% \text { ash in } \\
\text { waste }\end{array}$ \\
\hline 1850 & 808 & 24.5 & 3.1 & 0.25 & 3.0 & 239 & 3.2 & 3,250 & 16.3 \\
\hline 2100 & 716 & 26.4 & 3.3 & 0.25 & 3.2 & 286 & 3.8 & 3,866 & 16.5 \\
\hline
\end{tabular}


A simulation of a commercial system may need to have additional inlet streams of $\mathrm{SO}_{2}$, alkali, and flyash to simulate the commercial conditions. Two extreme cases are considered. The first, shown in Table 5.3, uses minimal coal input (only 5.4\% of ths total heat input), while the second case, shown in Table 5.4, uses maximum coal input (about 37\% of the total heat input). High heat losses are assumed, and no air preheating and no air enrichment are assumed. The same gas flow rate of 90 acfm is used. In the minimal coal feed case, using a coal containing 3 wt\% sulfur, the simulation requires additional $\mathrm{SO}_{2}$ gas and some additional alkali (in the form of $\mathrm{NaCl}$ mixed with the coal) to be injected. No additional $f l y$ ash is fed.

In the case of the maximum coal feed rate, a coal containing $1.5 \mathrm{wt \%}$ sulfur results in an acceptable simulation with no additional $\mathrm{SO}_{2}$ gas and with no additional alkali feed. In general, good simulations can be achieved, but the facility must be capable of running over the full range of extreme conditions. The resulting ranges of flow rates needed in the test facility are listed in Table 5.5, and these provide information needed to specify and design the facility components and auxiliaries.

Table 5.6 compares the estimated facility flow rates with the current capabilities of the facility to identify where changes are needed. Table 5.7 summarizes the materials consumption and test sample requirements for the test program. This identifies the material procurement needs and waste disposal needs for the program. Table 5.8 lists the equipment that may limit the length of continuous test runs, the feed bins for coal and for sorbent mixtures, and the solid waste collection hopper. Table 5.9 summarizes the the material supply needs, the material handling needs, and the analytical needs for the program. Table 5.10 summarizes the process measurements, sampling and process sample analytical needs. Together, the information in these tables define the basis for the equipment design and the program operational requirements. 
Table 5.3 - Bench-Scale Simulation with Small Coal Input

- Coal rate is 9 wt\% of methane rate (5.4\% of total heat input)

- Coal -- Pgh \#8; 3 wt\% S, 10 wt\% ash

- Coal contains $0.4 \%$ alkali $(\mathrm{Na}+\mathrm{K}) ; 3 \%$ alkali release

- $30 \%$ heat losses (10\%)

- Dolomite $\mathrm{Ca} / \mathrm{S}$ up to 3 ; sulfur removal $90 \%$

- $80^{\circ} \mathrm{F}$ air inlet temperature

- No slag removal

- No cyclone

- Operating pressure 10 atm

- Gas flow 90 acfm

- Criteria: same uncontrolled $\mathrm{SO}_{2}$, alkali, particle load

$\begin{array}{lll}\text { Temp (F): } & 1850 & 2100 \\ \text { Air }(\mathrm{Lb} / \mathrm{hr}): & 800(805) & 708(714) \\ \text { Coal (Lb/hr): } & 2.5(2.0) & 2.6(2.0) \\ \text { Methane (Lb/hr): } & 25.5(20.0) & 26.3(20.4) \\ \text { Sulfur gas (10\% S0})(\mathrm{Lb} / \mathrm{hr}): & 0.35(0.4) & 0.35(0.4) \\ \text { Alkali feed (NaCl) (Lb/hr): } & 0.006 & 0.006 \\ & & \\ \text { Ash feed (Lb/hr): } & 0 & 0 \\ \text { Sulfur sorbent (Lb/hr): } & 4.7(4.1) & 4.74(4.1) \\ \text { Alkali sorbent (Lb/hr): } & 0.25 & 0.25 \\ \text { Total mixed solids feed (Lb/hr) : } & 4.95(4.4) & 4.99(4.4) \\ & & \\ \text { Filter waste (Lb/hr): } & 3.7(3.4) & 3.7(3.4) \\ \text { Ash content of waste (\%): } & 6.8 & 7.0 \\ \text { Gas composition (uncontrolled) } & & \\ \text { S0 (ppmv): } & 245(214) & 274(238) \\ \text { alkali (ppmv): } & 2.9 & 3.2 \\ \text { part. load (ppmw): } & 3,986(3664) & 4,463(4062) \\ \text { Gas rate (Lb/hr): } & 928 & 837\end{array}$


Table 5.4 - Bench-Scale Simulation with Large Coal Input

- Coal rate is 50 wt\% of methane rate ( $36.7 \%$ of total heat input)

- Coal -- Pgh \#8; 1.5 wt\% S, 10 wt\% ash

- Coal contains $0.4 \%$ alkali $(\mathrm{Na}+\mathrm{K}) ; 3 \%$ alkali release

- $30 \%$ heat losses

- Dolomite $\mathrm{Ca} / \mathrm{S}$ up to 3 ; sulfur removal $90 \%$

- $80^{\circ} \mathrm{F}$ air inlet temperature

- No slag removal

- No cyclone

- Operating pressure 10 atm

- Gas flow 90 acfm

- Criteria: same uncontrolled $\mathrm{SO}_{2}$, alkali, particle load

$\operatorname{Temp}(\mathrm{F}):$

$\operatorname{Air}(\mathrm{Lb} / \mathrm{hr})$ :

Coal (Lb/hr):

Methane $(\mathrm{Lb} / \mathrm{hr})$ :

Sulfur gas $\left(10 \% \mathrm{SO}_{2}\right)(\mathrm{Lb} / \mathrm{hr})$ :

Alkali feed $(\mathrm{NaCl})$ ( $\mathrm{Lb} / \mathrm{hr})$ :

Ash feed (Lb/hr):

Sulfur sorbent (Lb/hr):

Alkali sorbent ( $\mathrm{Lb} / \mathrm{hr})$ :

Total mixed solids feed

Filter waste $(\mathrm{Lb} / \mathrm{hr})$ :

Ash content of waste (\%):

Gas composition (uncontrolled)

$\mathrm{SO}_{2}$ (ppmv) :

alkali (ppmv):

part. load (ppmw):
1850

797

17.1

17.1

0

0

0

4.8

0.25

5.1

5.2

32.9

248

2.2

5,630
2100

706

17.6

17.6

0

0

0

5.0

0.25

5.2

5.4

32.6

285

2.5

6,428 


\section{Table 5.5 - Bench-Scale Facility Flow Rate Ranges}

Air $(\mathrm{Lb} / \mathrm{hr})$ :

Methane (Lb/hr; scfm):

Coal (Lb/hr):

Coal transport $\mathrm{N}_{2}$ (scfm):

$\mathrm{SO}_{2}$ gas $(\mathrm{Lb} / \mathrm{hr})$ :

Fly ash (Lb/hr) :

Alkali (NaCl) (Lb/hr):

Sulfur sorbent (Lb/hr):

Alkali sorbent (Lb/hr) :

Additive ( $\mathrm{Lb} / \mathrm{hr})$ :

Total mixed solids ( $\mathrm{Lb} / \mathrm{hr})$ :

Solids transport air (scfm) :

Filter waste $(\mathrm{Lb} / \mathrm{hr})$ :

Gas rate $(\mathrm{Lb} / \mathrm{hr})$ :

Number $X-f l$ low elements:

candle elements:

$$
\begin{aligned}
& 700-810 \\
& 15-30(6-12) \\
& 2-20 \\
& 8
\end{aligned}
$$

$0 ; 0.3-2(0.08-0.5 \mathrm{scfm})$

0 (mix with coal if needed)

$0 ; 0.005-0.01$ (mix with coal)

$0 ; 1-5$

$0 ; 0.2-0.5$

$0 ; 0.2-2$

$0 ; 0.2-7.5$

14

$$
\begin{aligned}
& 0.2 ; 0.6-10 \\
& 800-950(180-220 \operatorname{scfm}) \\
& 2 \\
& 6
\end{aligned}
$$


Table 5.6 - Bench-Scale Facility Flow Rate Compatibility

Air :

Methane:

Coal:

Coal transport $\mathrm{N}_{2}$ :

$\mathrm{SO}_{2}$ gas $\left(10 \% \mathrm{SO}_{2}\right.$ in $\left.\mathrm{N}_{2}\right)$ :

Fly ash:

Alkali $(\mathrm{NaCl})$ :

Sulfur sorbent:

Alkali sorbent:

Additive:

Total mixed solids:

Solids transport air:

Filter waste:

Exhaust gas rate:
Compatible with Joy compressor

Compatible with methane compressor

Compatibie with K-Tron feed system

Compatible with current feed system

Commercially available; 5-31 hours per bottle

Premix with coal if needed

Premix with coal if needed

Independent and premixed feed tests

Premixed tests

Independent and premixed feed tests Need new K-Tron feed system; check ability to meet large operating range Compatible with current feed system

Much larger than current waste rate Compatible with current gas rate; new water-cooled exhaust line needed. 
Table 5.7 - Materials Consumption and Test Sample Requirements

Assumptions :

1) Total maximum test time of 100 hours

2) Each coal and sorbent sample capable of 50 hour operation

Materials Number samples Sample size Total material need

\begin{tabular}{|c|c|c|c|}
\hline Coal: & 2 & $1000 \mathrm{Lb}\left(4 \mathrm{BBL}^{*}\right)$ & $2000 \mathrm{Lb}\left(8 \mathrm{BBL}^{*}\right)$ \\
\hline $\mathrm{SO}_{2}$ gas: & $1\left(10 \% \mathrm{SO}_{2}\right)$ & 20 bottles & 20 bottles \\
\hline Fly ash: & 1 & very little & very little \\
\hline Alkali: & $1(\mathrm{NaCl})$ & very little & very little \\
\hline \multirow[t]{3}{*}{ Sulfur sorbent ( 3 ) } & dolomite & $250 \mathrm{Lb}(1 \mathrm{BBL})$ & $650 \mathrm{Lb}(3 \mathrm{BBL})$ \\
\hline & hydrated lime & $150 \mathrm{Lb}$ (1 BBL) & \\
\hline & limestone & $250 \mathrm{Lb}(1 \mathrm{BBL})$ & \\
\hline \multirow[t]{2}{*}{ Alkali sorbent (2) } & emathlite & $25 \mathrm{Lb}\left(1 \mathrm{ft} \mathrm{t}^{3}\right)$ & $50 \mathrm{Lb}\left(2-1 \mathrm{ft}^{3}\right.$ \\
\hline & hectorite & $25 \mathrm{Lb}\left(1 \mathrm{ft} \mathrm{t}^{3}\right)$ & containers) \\
\hline Additive & 2 (clays) & $100 \mathrm{Lb}\left(1 \mathrm{ft}^{3}\right)$ & $\begin{array}{l}200 \mathrm{Lb}\left(2-1 \mathrm{ft}^{3}\right. \\
\text { containers }\end{array}$ \\
\hline Mixed solids feed & 30 mixtures & varies widely & \\
\hline Filter waste & 34 & varies widely & $4-6 \mathrm{BBL}$ \\
\hline
\end{tabular}

* $\quad$ BBL $=55$ gal drum 


\section{Table 5.8 - Equipment Limits on Run Length}

Run length based on coal feed bin size $\left(2 \mathrm{ft}^{3}\right)$ :

- 3 hours (large coal input rate)

- 32 hours (small coal input rate)

Run length based on solids mixture feed bin size $\left(2 \mathrm{ft}^{3}\right): 9-90$ hours

Run length based on solid waste bin size $\left(3 f^{3}\right): 7-128$ hours 
Table 5.8 - Materials Supply, Handling and Analysis Needs

$\mathrm{SO}_{2}$ gas

Select supplier (premixed gas analysis provided)

Identify delivery time and maximum bottle storage time

Identify hazardous gas area requirements

Coals (2)

Coal specification (type, composition range, size, moisture) Identify supplier and preparer (size, dry, ship in drums)

Storage, handling and feeding requirements

Specify chemical/physical analyses and techniques to be used (eg., proximate, ultimate, alkali, size distribution)

Sulfur sorbents ( 3 )

Specify type, sizes and moisture

Identify suppliers and preparers (ship in drums)

Storage, handling and feeding requirements

Specify chemical/physical analyses and techniques to be used (eg., elemental analysis, alkali, size distribution, surface area, porosity)

Alkali sorbents (2)

Specify type, sizes and moisture

Identify suppliers and preparers (ship in drums)

Storage, handling and mixing requirements

Specify chemical/physical analyses and techniques to be used

(eg., elemental analysis, alkali, size distribution)

Additives (2)

Specify type, sizes and moisture

Identify suppliers and preparers

Storage, handling, feeding and mixing requirements

Specify chemical/physical analyses (eg., elemental analysis, alkali, size distribution)

Solids mixtures (10)

Specify mixture ratio and quantities needed

Determine mixing method

Storage, handling and feeding requirements

Solid waste

Identify disposal method

Storage and handling requirements

Specify chemical/physical analyses and techniques to be used

(eg., Ca, S, alkali, size distribution) 
Table 5.10 - Process Measurements, Sampling and Analysis Needs

Filter exhaust gas

Total rate (continuous; low temp; $180-220 \mathrm{scfm}$ )

$\mathrm{O}_{2}, \mathrm{CO}_{2}$ (continuous; low temp; 5 to 10 vol\%)

$\mathrm{Sf}_{2}$ (continuous; low temp; 200-300 ppm uncontrolled; down to 20-30 ppm controlled)

Alkali (batch; high temp; $1-10 \mathrm{ppm}$ controlled; down to $50 \mathrm{ppb}$ ) ** $(\mathrm{NO})$ (periodic; low temp)

particulate content (periodic; low temp; 1 - 10 ppm)***

Filter inlet gas

SO (periodic continuous; high temp; $200-300 \mathrm{ppm}$ down to 20-30 ppm)*

Alkali (batch; $1-10 \mathrm{ppm}$ down to $50 \mathrm{ppb}$ )

Solid waste

Batch collection weight

Chemical/physical properties of batch

Flow properties (eg., angle of repose)

Feed solids

Mixture ratios

Feed rates

Feed gases

Pressures and feed rates

Combustor temperature data

Filter data and examinations

Pressure drop record and temperature profile

Blowback cleaning frequency

Filter element deposit and durability examination

Visual examination of elements and other internals (shroud, tube sheet)

-

*: Select preferred instrumentation and procedures, and design gas sample conditioning and control trains

**: Westinghouse STC alkali probe

***: Current Westinghouse STC particulate measurement technique 
Test materials procured are:

- 2.5 tons of Kittanning Seam coal, micronized to $90 \%<325$ mesh, containing about $11 \mathrm{wt} \%$ ash and $4.4 \mathrm{wt} \%$ sulfur.

- $200 \mathrm{lb}$ of pulverized emathlite from MFM.

- Small samples (10 1b) of commercial, micronized dolomite, used in preliminary testing.

\subsection{COAL-NATURAL GAS COYBUSTOR DESIGN CRITERIA}

Objectives of Combustor: Produce combustion gas at specified rate, temperature, and pressure containing coal ash particles that have been exposed to representative temperature conditions to simulate direct coal-fired turbine combustors. $\mathrm{NO}_{x}$ emissions and carbon combustion efficiency do not have required performance levels.

Required Capacity and Conditions: Produce 80 acfm gas at 1850 $2100^{\circ} \mathrm{F}$ and $10 \mathrm{~atm}$ (nominal heat input of $600,000 \mathrm{Btu} / \mathrm{hr}$ ).

Combustor Concept: Primary zone combustion of methane and coal (maximum coal input of $35 \%$ of total energy) under lean conditions with axial injection of both fuels. Secondary zone dilution with multiple, radial nozzle injection of air to desired gas temperature.

\section{Criteria:}

- primary zone exit temperature $2800^{\circ} \mathrm{F}$

- primary zone residence time greater than $0.1 \mathrm{sec}$

- primary zone ID > 5 times coal nozzle diameter

- secondary zone outlet temperature of $1850-2100^{\circ} \mathrm{F}$

- secondary zone residence time $0.1-0.2 \mathrm{sec}$ 


\section{Assumptions:}

- primary zone heat 10ss $20 \%$ of heat input

- secondary zone heat loss $10 \%$ of heat input

- complete coal/methane combustion in primary zone

\section{Combustor Dimensions}

The combustor dimensions are summarized in Table 5.11. 
Table 5.11 - Combustor Flow Rates and Dimensions

Gas Delivery Temperature ( $\mathrm{P})$ :

Methane Flow (Lb/hr, scfm):

Coal Rate $(\mathrm{Lb} / \mathrm{hr})$ :

Coal Transport $\mathrm{N}_{2}$ (Lb/hr, scfm):

Primary Air Rate (Lb/hr):

Secondary Air Rate (Lb/hr):

Solids Trans. Air (Lb/hr, scfm):

Primary Gas Flow (acfm):
1850

$17.1(7.0)$

17.1

$35(8)$

616

182

62 (14)

83.5
2100

$17.6(7.2)$

17.6

35 (8)

640

66

62 (14)

97

Primary Zone:

$\begin{array}{llll}\begin{array}{c}\text { Diameter } \\ \text { (inch) }\end{array} & \begin{array}{c}\text { Length } \\ (\mathrm{ft})\end{array} & \begin{array}{c}\text { Velocity } \\ (\mathrm{ft} / \mathrm{s})\end{array} & \mathrm{N}_{\mathrm{Re}} \\ 1 & 29.4 & 294 & 7,700 \\ 2 & 7.3 & 73 & 3,800 \\ 3 & 3.3 & 33 & 2,600 \\ 4 & 1.8 & 18 & 1,800 \\ 5 & 1.2 & 12 & 1,600\end{array}$

Secondary Zone:

$\begin{array}{ll}\begin{array}{c}\text { Diameter } \\ \text { (Inch) }\end{array} & \begin{array}{c}\text { Length } \\ (f t)\end{array} \\ 1 & 27.5-55.0 \\ 2 & 6.9-13.8 \\ 3 & 3.1-6.1 \\ 4 & 1.7-3.4 \\ 5 & 1.1-2.2\end{array}$

Volocity
$(\mathrm{ft} / \mathrm{s})$
275
68
31
17
11

$N_{R e}$

$10.600-11,800$

$5,300-6,000$

$3,500-4,000$

2,700-3,000

$2,100-2,400$ 


\section{EQUIPMENT DESIGNS}

A preliminary assembly drawing of the facility, Figure 6.1, was completed, showing the new combustor, the filter pressure vessel with the new internals (tubesheet, candles, liner and insulation), and the outlet piping. The tubesheet supports six Coors mullite candles, each of 1 meter length. The design of the structural alterations to support the new combustor and associated equipment are shown in Figure 6.2 (drawing M-12). The outlot piping includes a sampling section with two ports that can be used for gas sampling in the test program. The watercooled exhaust piping design details are shown in Figure 6.3 (drawing $M-11$ ).

The tubesheet details are shown in Figure 6.4.

The coal/natural gas combustor dotails are shown in Figures 6.5 and 6.6 .

Material-of-construction recommendation for the filter vessel liners were evaluated, and detailed drawings for the vessel liners were completed, and are shown in Figures 6.7 through 6.8. (drawings 2D28818, 2D28818, 2D28820).

The need for a new dust collection vessel has been identified, and a detailed drawing of that vessel is shown in Figure 6.10 (0305E70).

Three brief test efforts have been identified to support and confirm the ILEC filter design -- a cold flow model test of the inlet gas configuration to the filter vessel, an oven test of candle filter and gasket durability at the elevated temperatures of the filter testing, and a test of deposit additive performance. 


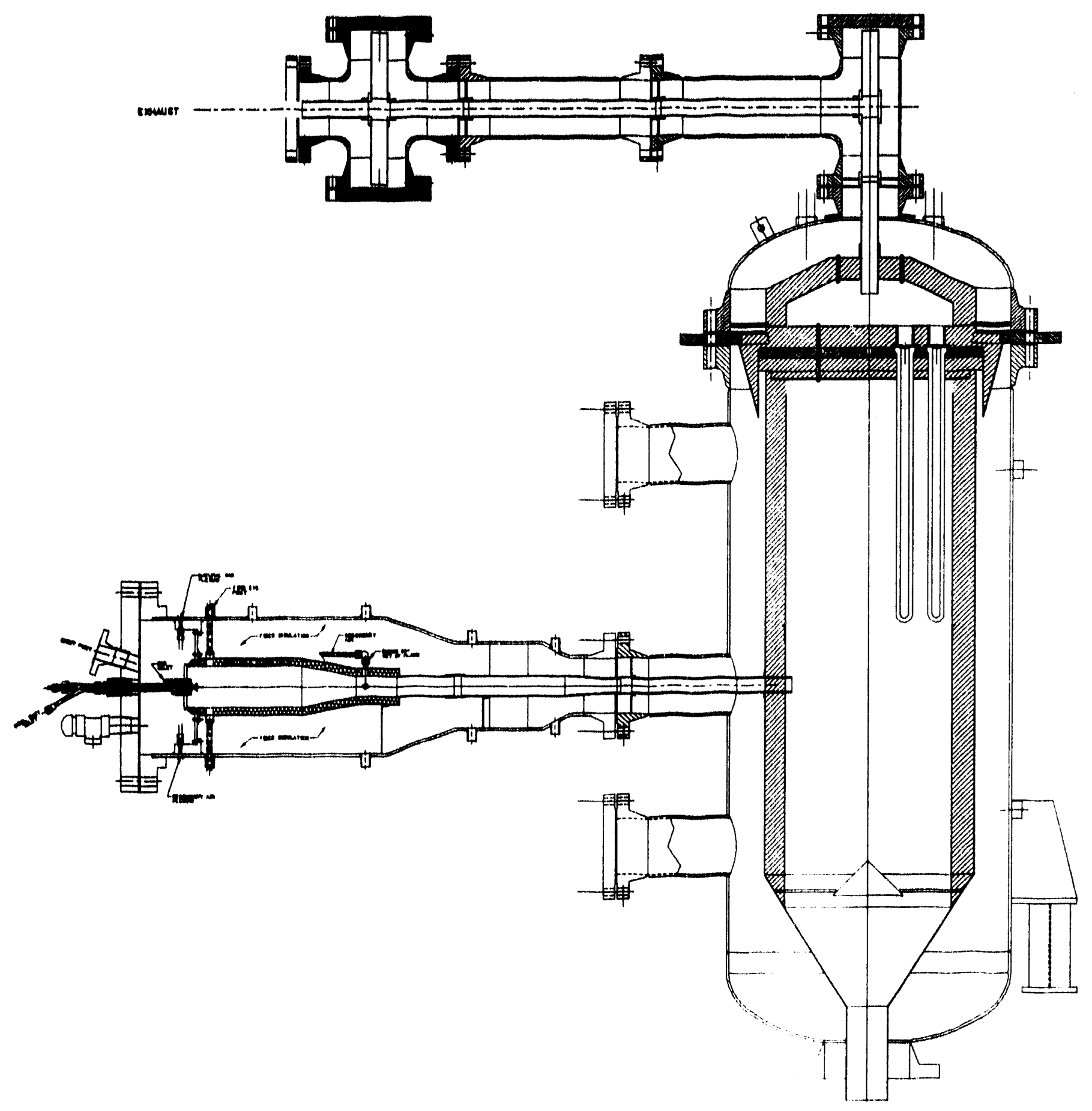

Figure 6.1 - Assembly Drawing 


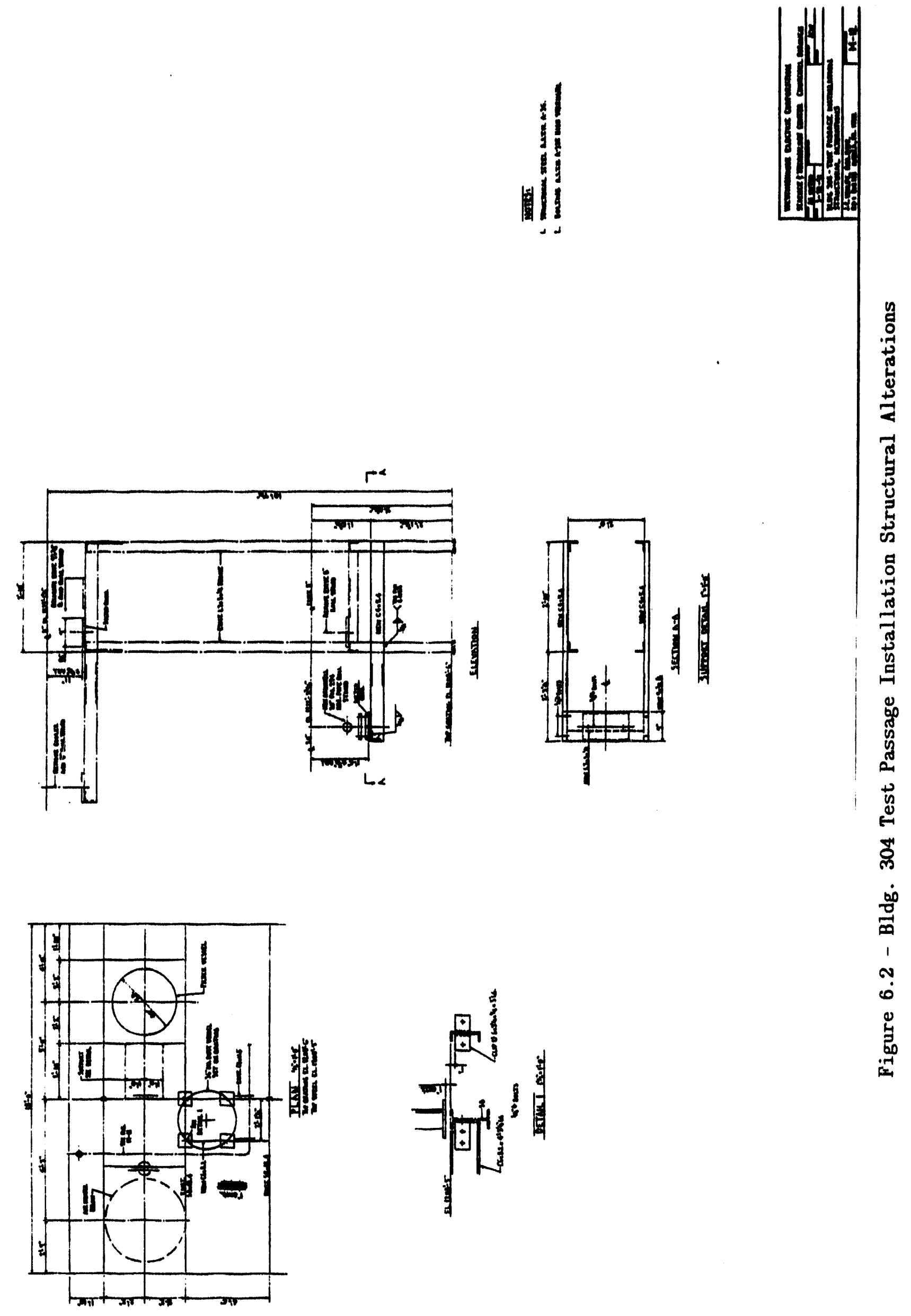



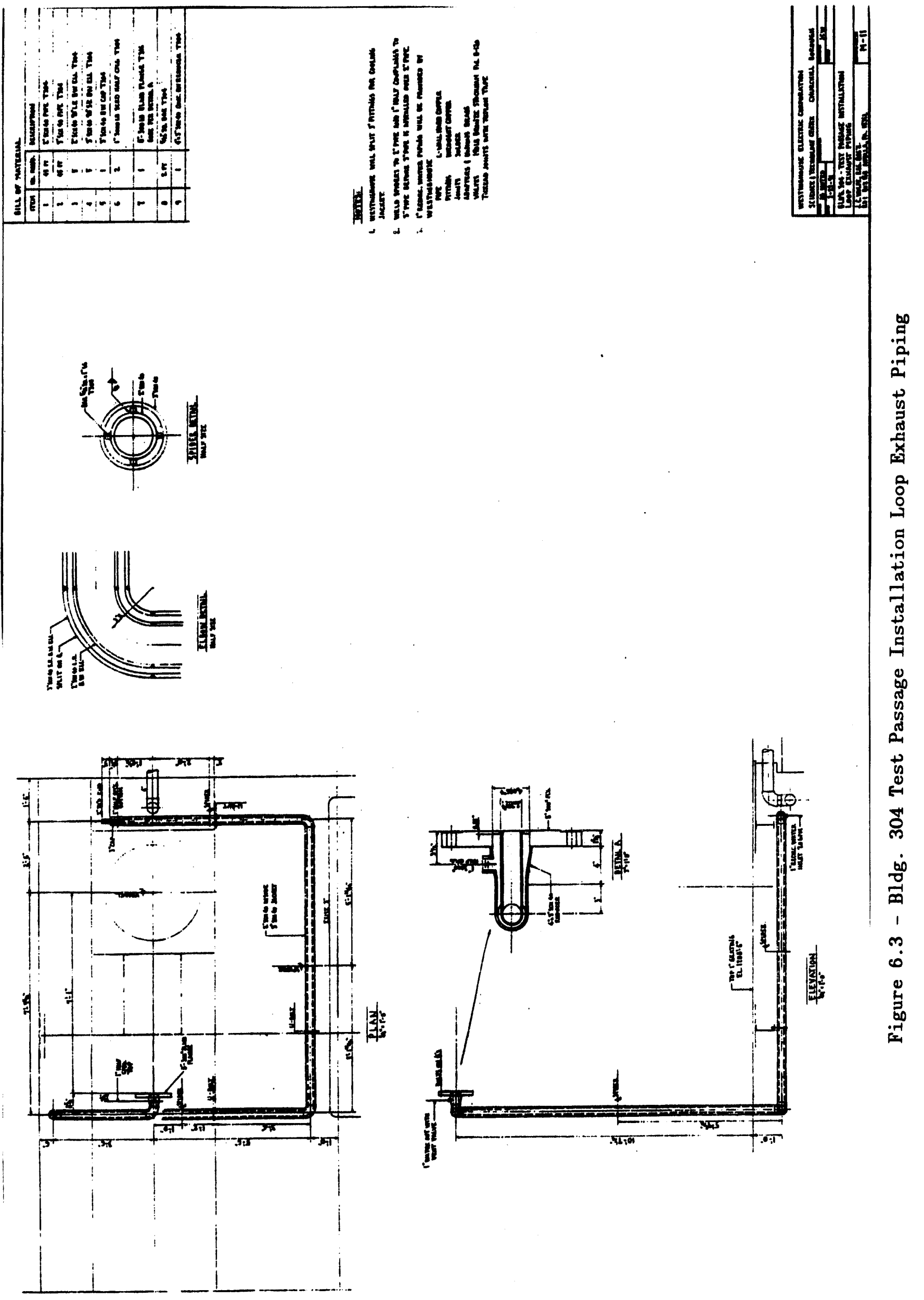


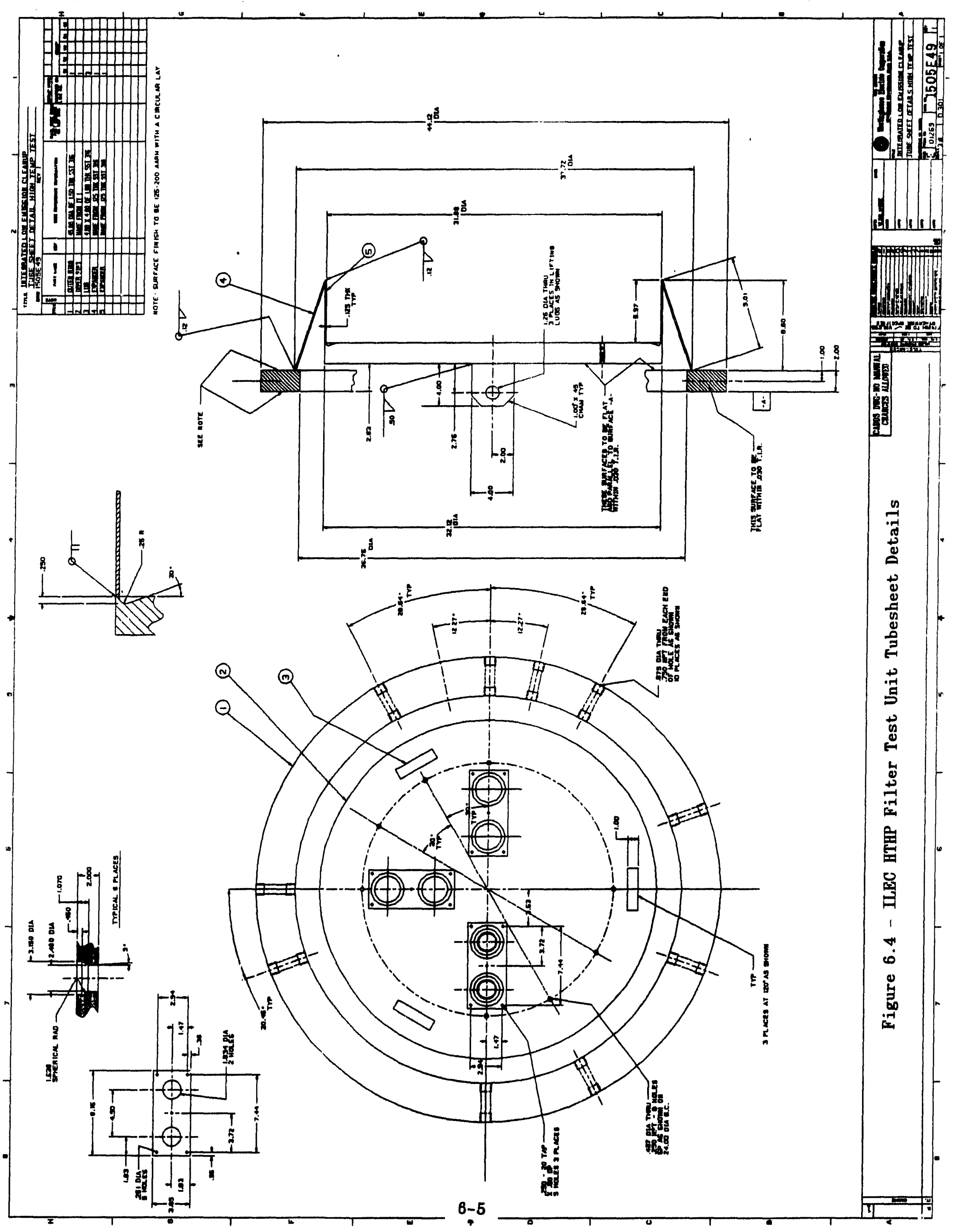




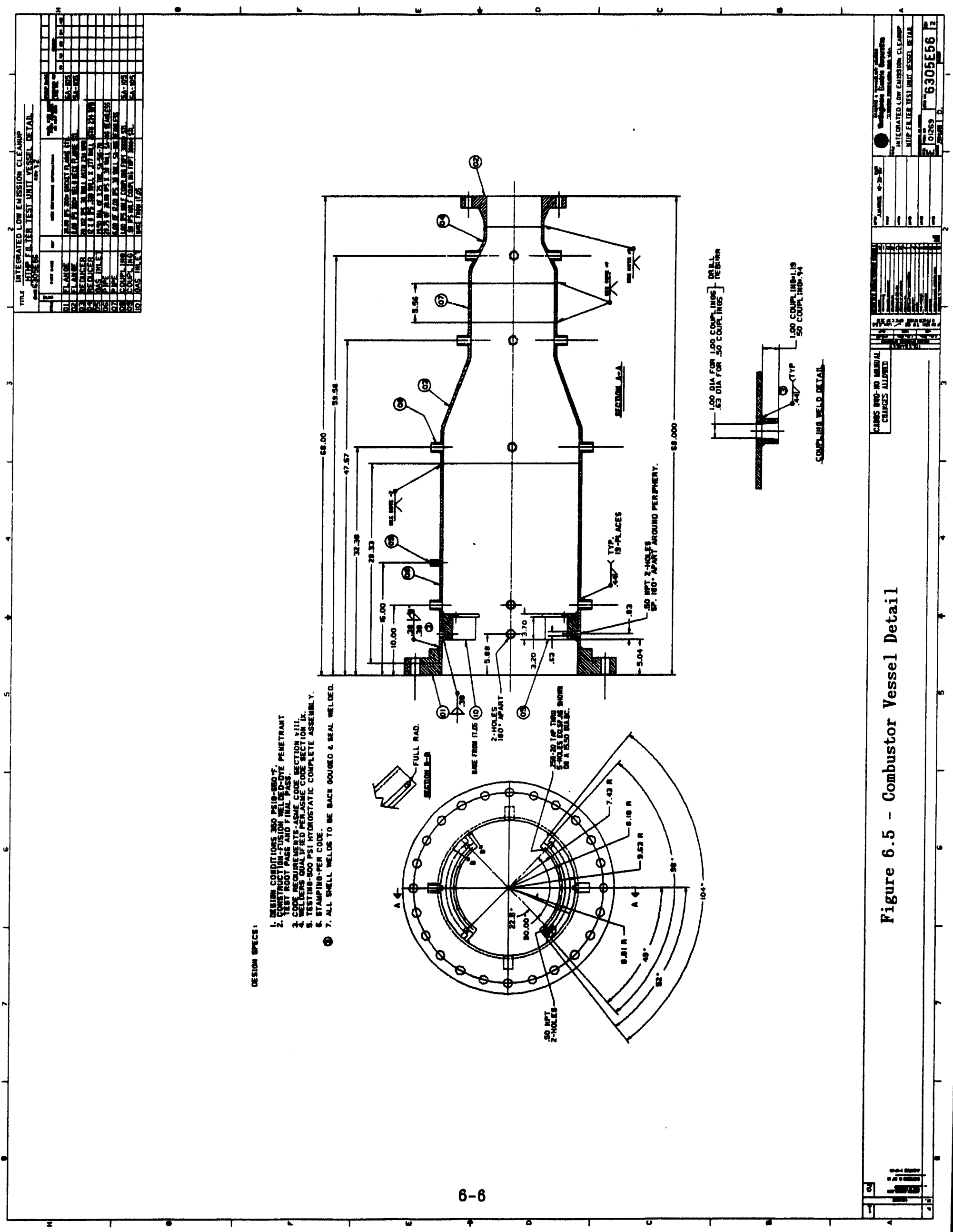




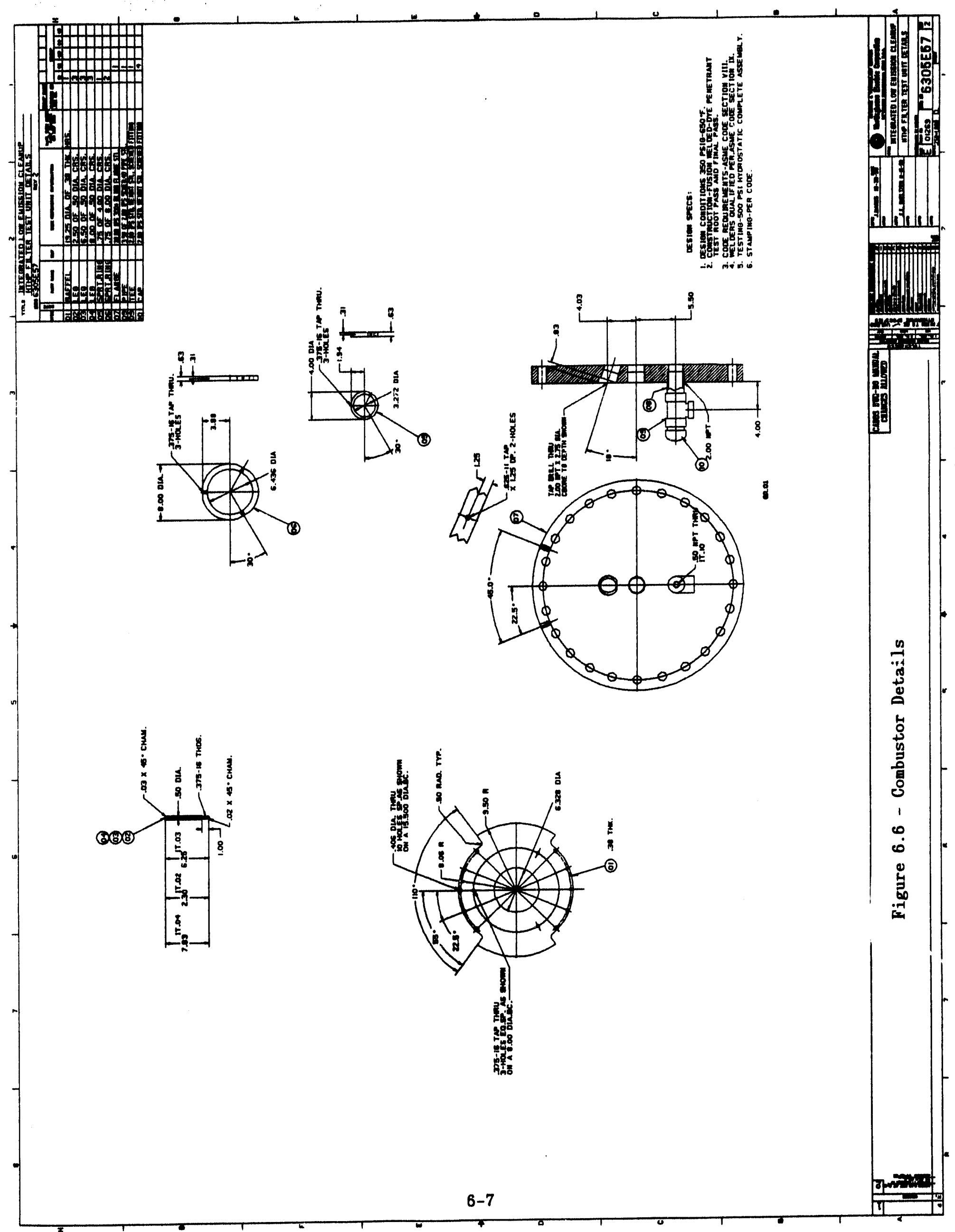




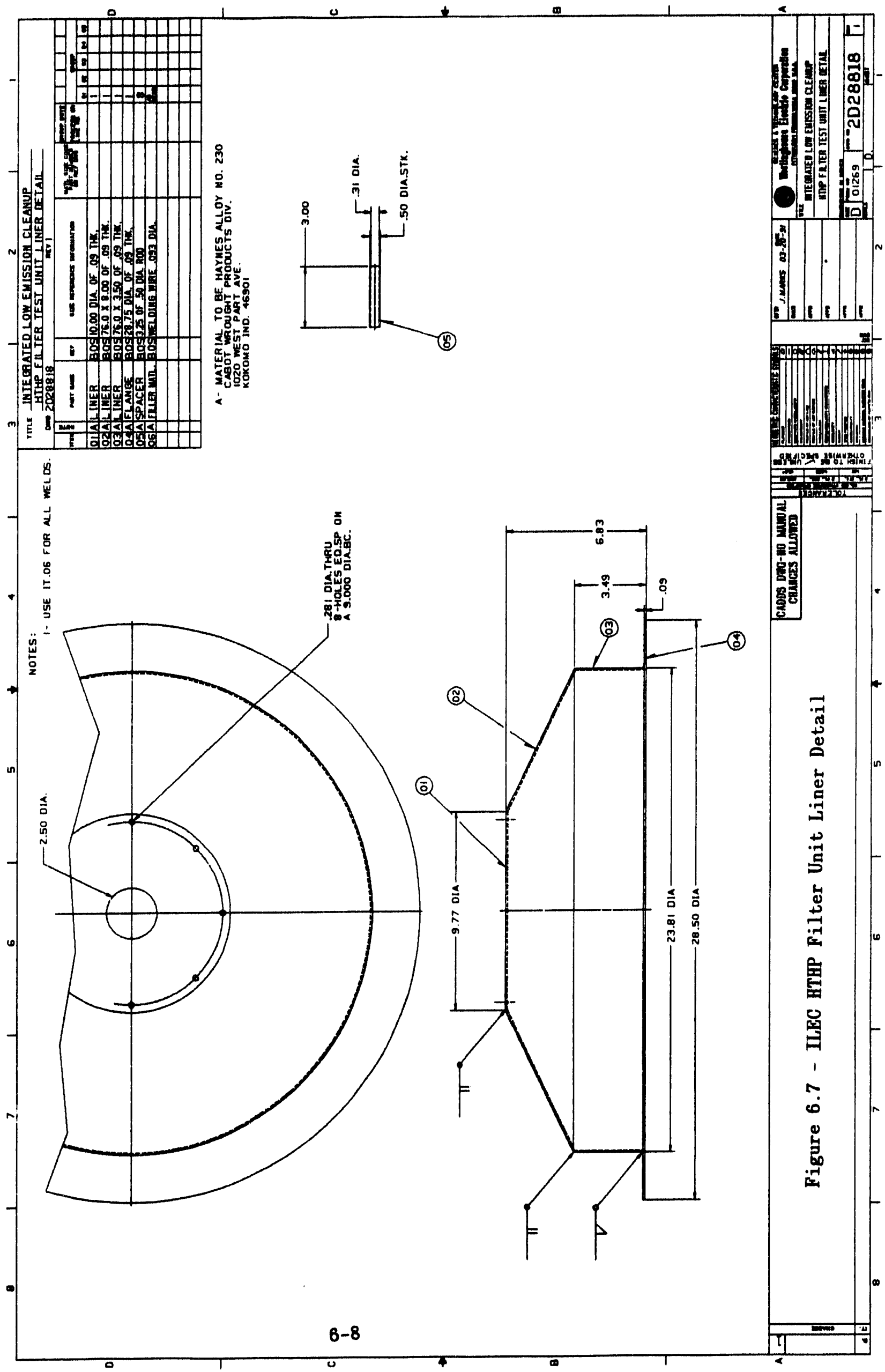




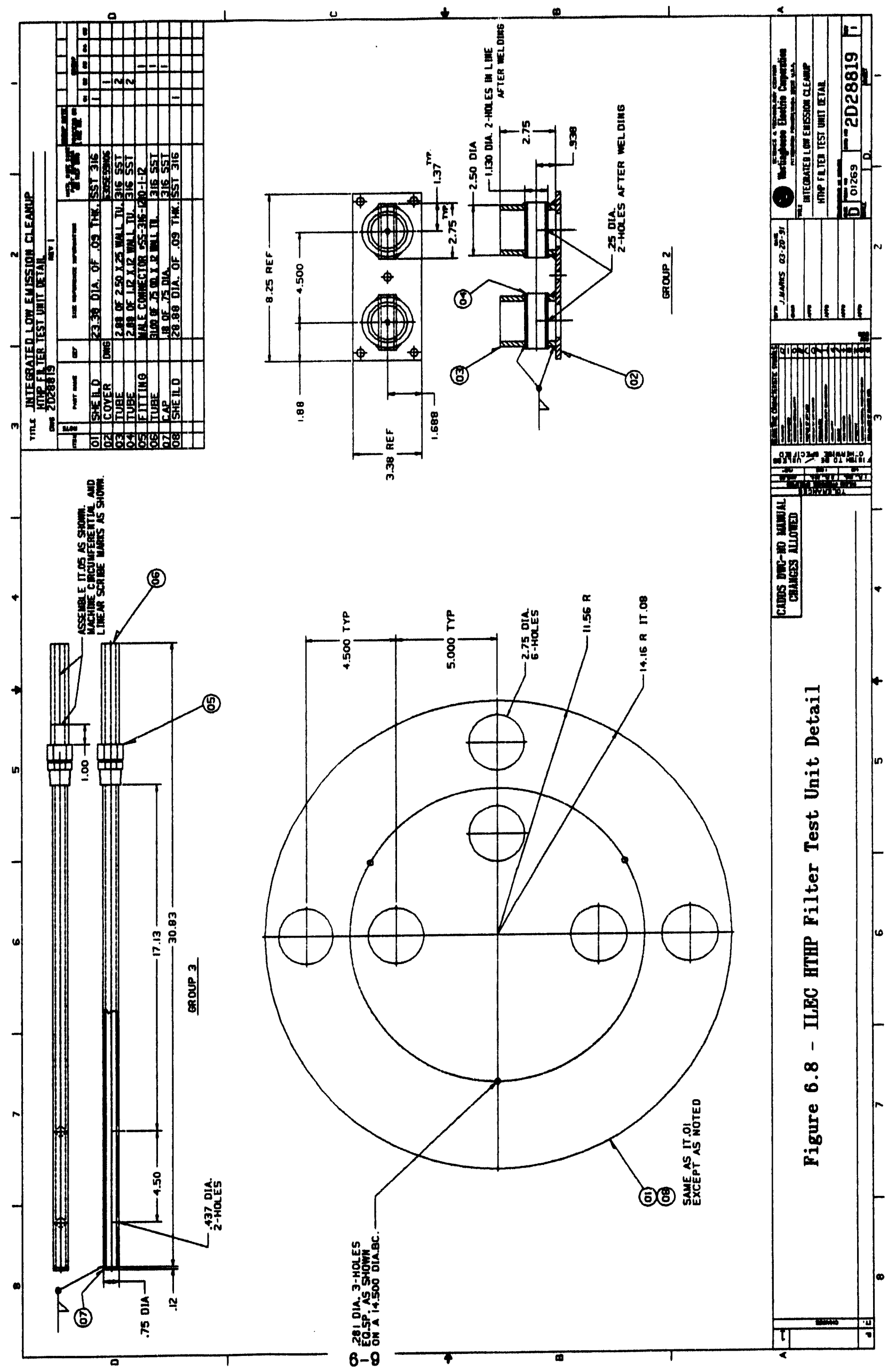




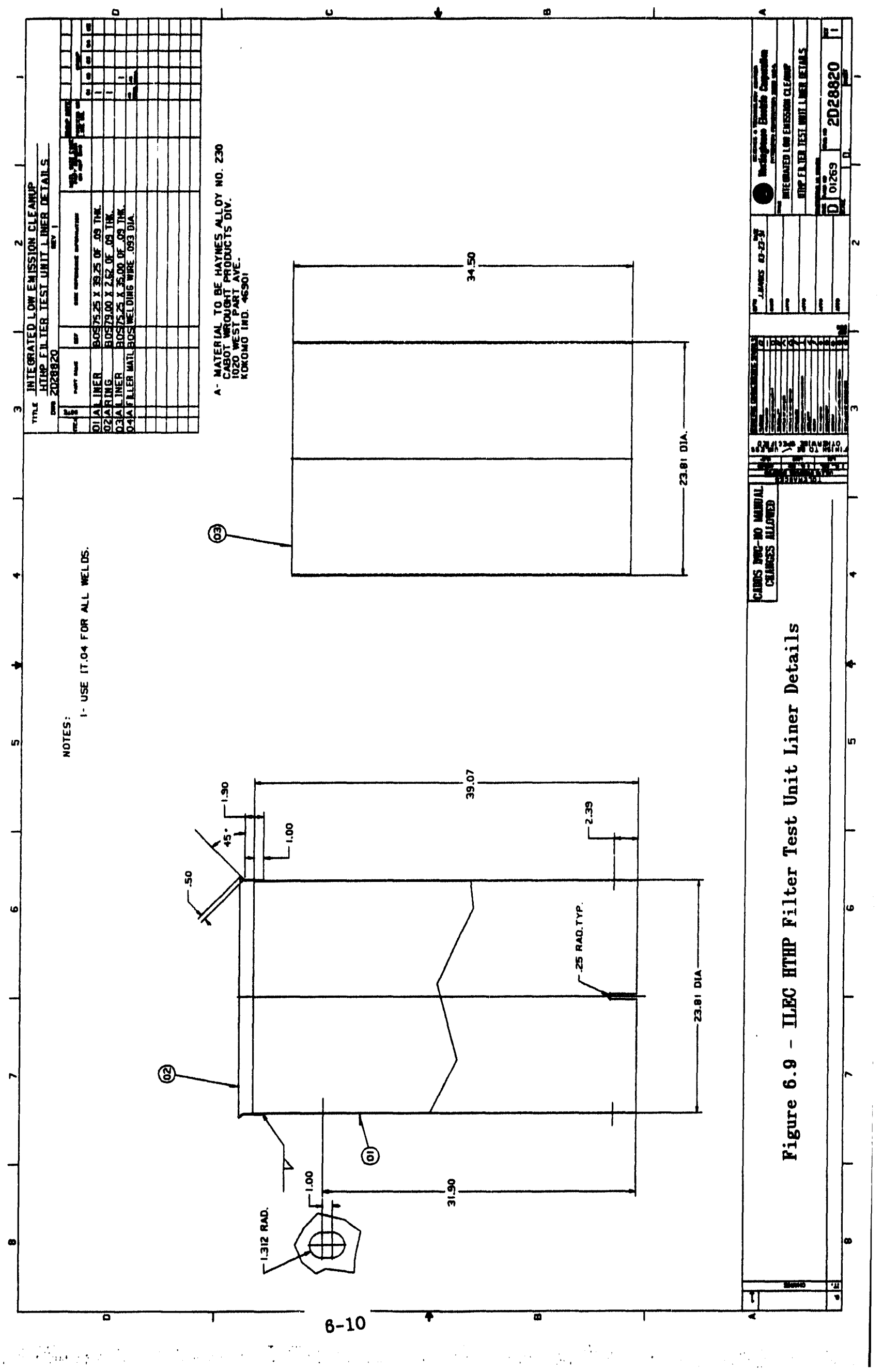




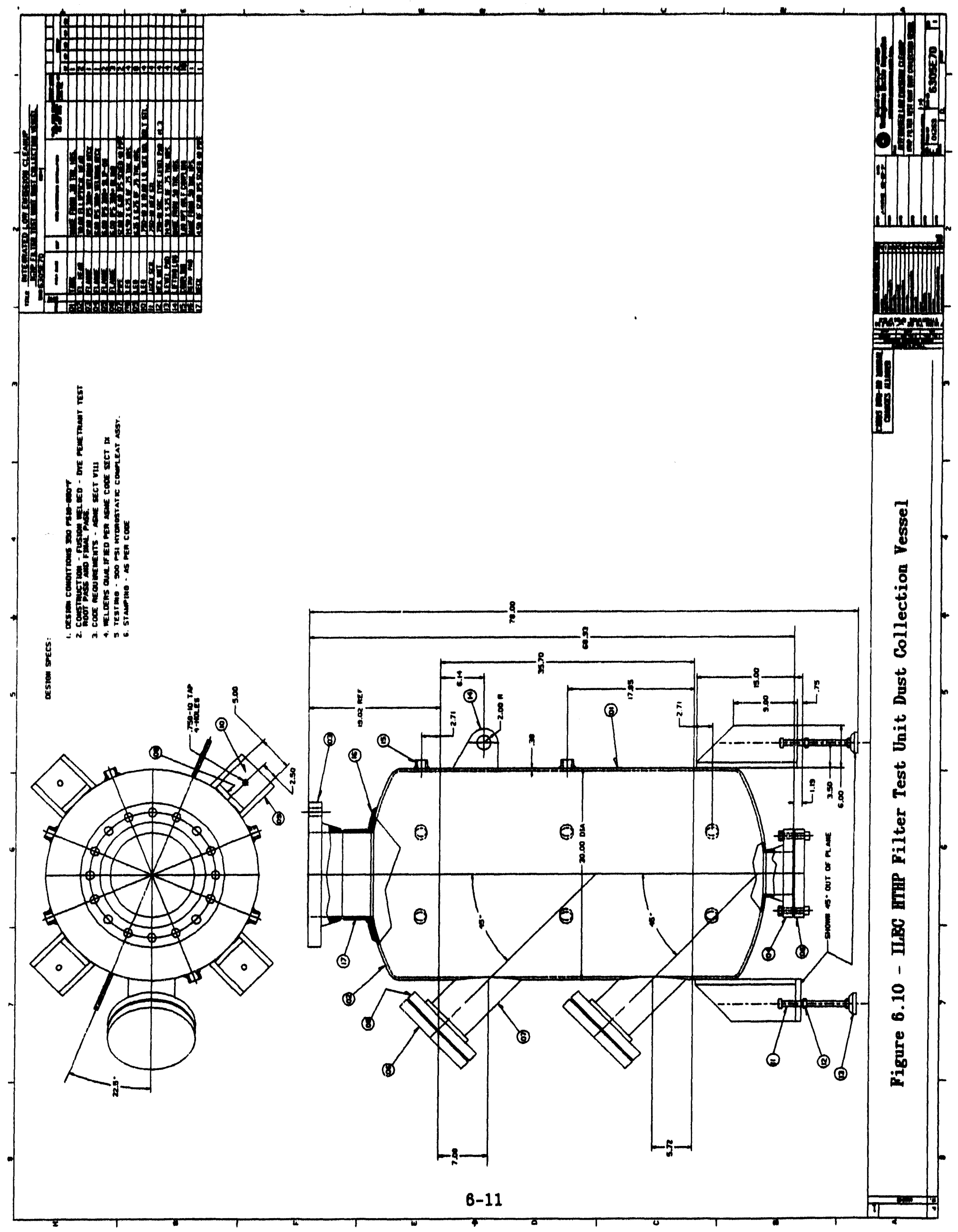


Filter Vesael Gas Inlet Configuration

The ATHP gas enters the filter vessel radially through a $2^{n}$ ID nozzle at a velocity of nominally $70 \mathrm{ft} / \mathrm{s}$. No baffle has been placed at the nozzle exit to deflect the gas, this being specifically avoided so that slag impaction removal will not occur. The inlet nozzle is 8 " below the bottom of the candles, and the six candles are arranged so that the upward directed eddy that will be produced will not impinge directly on the candles. There is still concern that the gas velocity over the candle elements may be excessive and cause vibration or impact damage to the candles.

An existing filter cold flow model facility has been used to conduct some tests to verify visually that no concern exists at least for the relatively short duration testing in this unit. The cold flow model is a Plexiglas vessel having dimensions almost identical to the HTHP unit. A radial gas inlet was inserted in the facility and piped to a level where inlet air was introduced eight inches below the candles. Six candles were arranged in the vessel to have a configuration similar to the HTHP candle configuration. The air flow was set to have an inlet flow and velocity identical with the HTHP unit. Several smoke generators where dropped into the conical base of the vessel and observations made of the gas flow profile from the nozale and throughout the vessel. The jet issued from the nozzle reached across the vessel and was deflected tangentially outward causing two recirculating gas loops that travelled up the vessel, and a stream moving down the center of the ressel must also have existed, although it could not be seen through the dense smoke. Gas velocities were relatively low after the jet was deflected, and no vibration or motion of the candles was detected. It is possible that erosion might occur on the metal liner directly across from the nozzle, or a deposit might form on the liner at that point. Neither of these would be of significant concern over that duration of the test program. 
A second phase of testing was conducted to compare the observed gas flow profiles when using a simple inlet flow device that will direct the inlet gas sightly downward to dissipate the jet further from the candles. This inlet configuration was selected also for its simplification of design and ease of support at the high temperature conditions. The gas flow pattern was not improved by having a baffle on the inlet to deflect the gas downward. The mixing within the vessel was just as intense as without the baffle and the gas flow pattern was very similar except that there was more mixing within the conical region at the base of the ressel. It is concluded that the design having no inlet gas baffle is acceptable for the test program.

Candle and Gasket Durability Testing

Some concern exists that the candle and gasket materials may not tolerate the high-temperature environment in this application even for the short test duration. A simple oven test was initiated to subject candle filter elements and gasket materials to high temperatures for relatively long periods of time. Three candle sections of different ceramic materials, and ten candidate gasket materials have been placed in an oven, in air, for 400 hour exposure at $2100^{\circ} \mathrm{F}$. The candle elements were removed and characterized for strength and permeability relative to their virgin properties. The gasket materials physical structures were observed after the test. It was concluded that the oxide-based, Coors mullite candles are the best candidates for the high temperature conditions of the test program. The gasket materials tested were sufficiently durable for the short term testing.

Filter Cake Additive Tests

A filter cake additive test was performed in an existing facility having the same flow capabilities as the modified test facility. Testing was conducted under simulated PFBC conditions at a 
temperature of about $1600^{\circ} \mathrm{F}$ using known difficult PFBO flyash (Grimethorpe "Red" from Run 129). Comparison tests were performed first with the infected flyash containing no additive, resulting in increasing filter preseure drop with extended time until sufficient pulse cleaning could not be obtained. Adding $10 \mathrm{wt \%}$ micronised dolomite to the flyash, representing lese than 5 volume $\%$ additive of dolomite, resulted in much improved performance with lower presoure drop and easier cleaning. The details from this teat have been reported ${ }^{5}$. 


\section{SHAKEDOWN TESTS}

A veries of shakedown tests were conducted to confirm the operation of the modified test loop over the range of conditions necessary to conduct the test program. All of the subsystems performed as designed and the necessary flow rates, pressure, and temperatures can be achieved. 


\section{CONOLUSIONS}

The bench-scale test facility has been modified to have the capabilities to conduct the proposed test program. It is recommended that the Phase III test and evaluation program be initiated by DOE. 


\section{REFERENCES}

1. Logan, R. G., et al., A Study of Techniques for Reducing Ash Deposition in Coal-Fired Gas Turbines, Presented at the 187th ACS National Meeting, Dallas, TX, April 1889.

2. Spiro, C. L., et al., Deposit Remediation in Coal-Fired Gas Turbines Through the Use of Additives, Presented at the 187 th ACS National Meeting, Dallas, TX, April 1889.

3. Horner, M. W., et al., GE Gas Turbine Environmental and Deposition Control, Proceedings of the Annual Coal Fuel Heat Engineers and Gas Stream Cleanup Systems Contractors Review Meeting, DOE/METC-88/6094, June 1988.

4. Bachovchin, D. M., et al., A Study of High-Temperature Alkali Removal in a Pressurized Gasification System, Final Report, 1886, DOE/MO/20050-2226.

5. Lippert, T. E., et al, Integrated Low Emissions Oleanup System for Direct Coal-Fueled Turbines, Proceedings of the Ninth Annual CoalFueled Heat Engines, Advanced Pressurized Fludized-Bed Combustion and Gas Stream Cleanup Systems Contractors Review Meeting, October 1892 (DOE/METC-93/6129. 

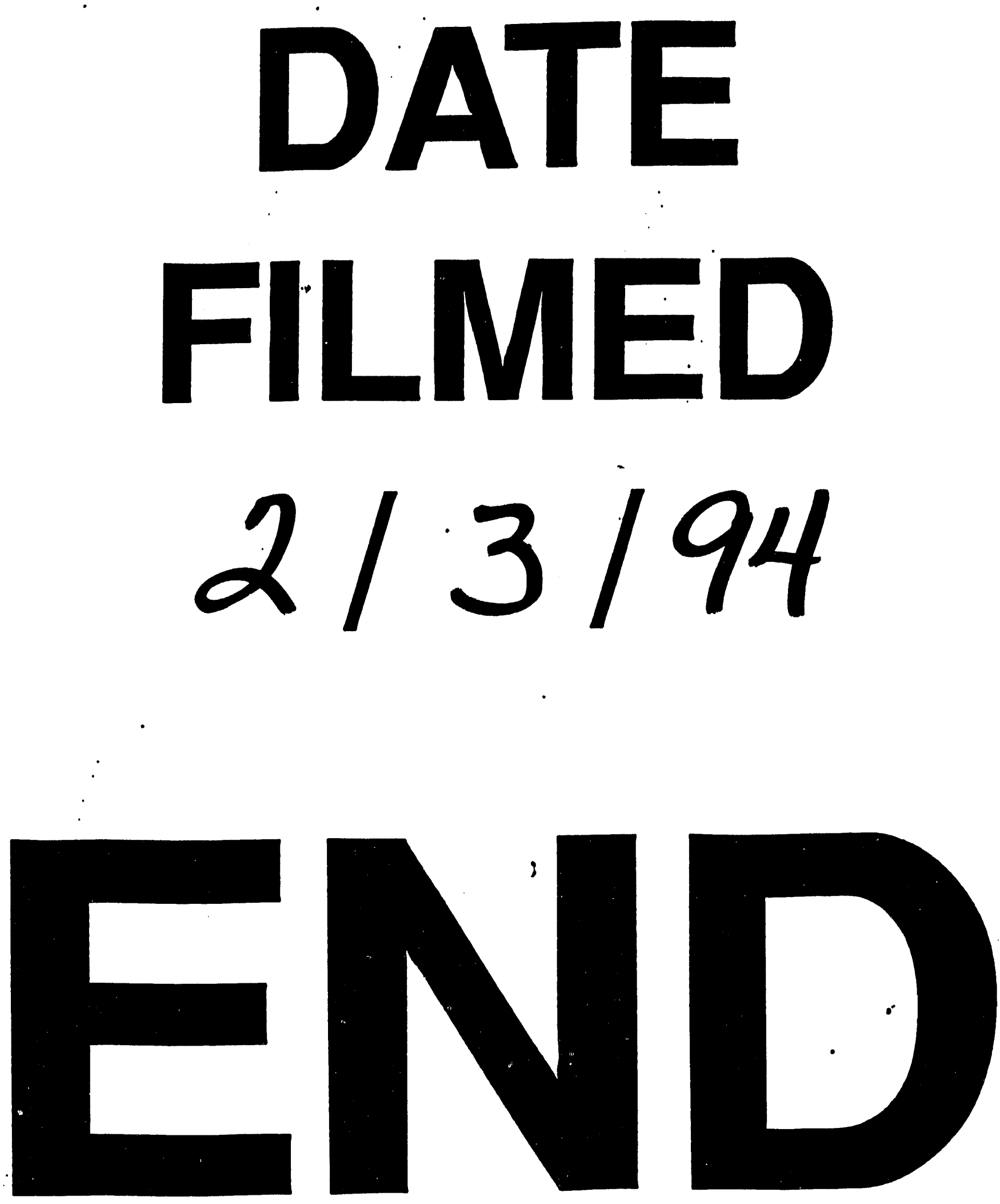
